\title{
Urologische Diagnostik und Therapie
}

für

\section{Ärzte und Studierende}

Von

Dr. H. Boeminghaus

a.o. Professor für Chirurgie an der Universität Marburg/L.

Zweite, erweiterte Auflage

Mit 134 teils farbigen Abbildungen im Text

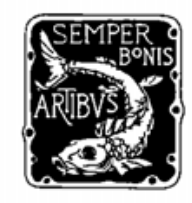

Jena
Verlag von Gustav Fischer
1931 
Alle Rechte vorbehalten

Printed in Germany

Druck von Ant. Kämpfe, Jena 